\title{
Review
}

\section{The misguided search for the political: Social weightlessness in radical democratic theory}

\author{
Lois McNay \\ Polity, Cambridge, 2014, 250pp., ISBN: 978-0745662635
}

Contemporary Political Theory (2015) 14, e5-e8. doi:10.1057/cpt.2014.56;

published online 10 February 2015

Often political theorists will skirt around the big questions they really want to pose at the risk of appearing too bold, or perhaps even brash. It is to Lois McNay's credit that no such reserve is allowed to impede the pursuit of her central aim in this book, which is no less than to address the matter of what political theory ought to be about. The answer McNay puts forward to that question is, to put it summarily, 'disclosing critique', but in its explication it involves a probing examination of the standing of radical democratic theory, cast more specifically as theory of the agonistic kind. The chief error committed by proponents of agonistic democracy results from a compliance with the Zeitgeist of contemporary political theory, and its obsession with the idea of establishing the autonomy and primacy of 'the political'. McNay thinks this search is 'misguided' as it promotes two interrelated moves in thought that enfeeble political theory as a form of effective critique: idealisation (as opposed to abstraction) and the repudiation of 'the social' in general, and sociological modes of inquiry in particular. In its constructive moment, McNay's argument points to an alternative formulation of political theory as abstraction (not idealisation) from concrete social relations, disclosing in them the conditions of power that inhibit democratic participation by generating social suffering - those feelings of marginalisation, powerlessness and worthlessness experienced by large numbers of people in contemporary neoliberal capitalist societies. This is a powerful vision of what a genuinely radical and critical political theory could be, built on some serious criticisms of agonistic democratic theory that are, to a large degree, unanswerable. Yet at the same time, McNay's approach invites some cautionary notes - this reconstruction of radical democratic and political theory seems at times too hasty and too confident about what it can achieve.

The charges that McNay brings against agonistic democratic theory are shaped by considerations of sociologically oriented accounts of the character of current social conditions in neoliberal capitalism. The principal figure here is Pierre Bourdieu, whose work on social suffering McNay uses as the grounds of her indictment of

(C) 2015 Macmillan Publishers Ltd. 1470-8914 Contemporary Political Theory Vol. 14, 4, e5-e8 
agonistic theory for its 'social weightlessness', but Axel Honneth's application of Bourdieu's take on social suffering to matters of political theory is also important. Social suffering, in this Bourdieusian sense, refers to the manner in which quotidian suffering is not a property of individual experience, but rather a product of relations of power, the internalisation of relations of domination or the effects of 'symbolic violence', all captured in Bourdieu's notion of 'habitus' (p. 19). Such suffering is promoted by the individualising tendencies of neoliberal government, where the notion of 'self-responsibility' serves to divide the poor and disguises the structured social and economic inequalities responsible for heightened levels of social misery. This emphasis on social suffering is designed to counter a tendency in academic work towards 'social weightlessness', the temptation endemic in scholastic endeavours to abstraction to the point of idealisation and the repudiation of 'the world of ordinary practices' (p. 40).

The value of Bourdieu's critique of social weightlessness for McNay's inquiry is that it "casts doubt on the rationale of theoretical approaches whose main aim is to isolate an essential political logic (deliberation or otherwise) and, on this basis, construct a definitive model of democracy' (p. 42). The recognition of the 'ordinary violences' that are often ignored in the discourses of democratic theory is prompted by an emphasis on social suffering, as is a recognition of the 'social conditions necessary for effective agency' (p. 45). McNay invokes Honneth's work because of its application of these insights to political thought in light of his theory of recognition. Honneth sees social suffering as a result of the misrecognition of and derision heaped upon the poorest and most marginal members of society. This does not amount to a reductive politics of identity, because Honneth, following Bourdieu, identifies such suffering as embedded in the social structures generative of habitus. As a self-avowed contributor to the tradition of Critical Theory, Honneth tasks that tradition with a rediscovery of its critical social and political dimensions through the idea of 'disclosing critique': the unmasking of forms of domination that have previously gone unrecognised, forms embedded in the everyday experiences of the poor and excluded. Despite reservations about the universal ethical implications of recognition that Honneth propounds in his later work, it is this notion of disclosing critique as the exposure of the depoliticising effects of domination that is key to McNay's criticisms of agonistic democratic theory and her redrawing of the purposes of a critical political theory.

The bulk of the book is made up of critical commentaries on the work of a number of thinkers who may be regarded as agonistic democratic theorists: Chantal Mouffe, Wendy Brown, Linda Zerilli, Jacques Rancière, William Connolly and James Tully. But I will pass only briefly over these chapters, because as I said at the top of the review, I think McNay's criticisms of the selected thinkers are both important and in the main unanswerable. They largely speak for themselves. Of particular note in these chapters is McNay's revelation of Mouffe's theory of power as 'not a theory of power at all' but rather a 'generalized theory of signification' incapable of capturing 
'embodied dynamics of oppression and inequality in anything other than the most formulaic dualisms of stasis and flux, inclusion and exclusion, essentialism and antiessentialism' (p. 79); the paradox of Rancière's 'empty' account of politics - 'It is an account of radical democracy that asserts an absolute sympathy with the voices of the excluded but dismisses out of hand most real-world attempts to make those voices heard' (p. 167); and the socially weightless presupposition of agency as either a feature of the ontology of abundance or membership of a subaltern community to be found, respectively, in the work of Connolly and Tully. The aim of exposing the deficiencies of approaches that seek to establish the idea of the autonomy and primacy of the political is amply met by McNay in these chapters. But the argument is not simply one in theory; the political force of this critique is to the front, and we are left with a persuasive argument against the political relevance of what passes for radical democratic theory in the present.

Nonetheless, there are two significant notes of caution to sound. The first relates to the political force of McNay's critique. The accusation that she vindicates the politics of paternalism does not stick, for at a number of points she makes the case that the recognition of the deeply embedded structural character of poverty and marginalisation is necessary for establishing what are the conditions for a more emancipatory and participatory democratic politics. An understanding of social suffering acts as a means of complementing a more 'constructive' approach that focuses on (potential) forms of everyday political agency. Yet the balance between these two approaches is hard to get right. It is difficult to read the claim made by Charlesworth used to back up McNay's illustration of the depth of 'dispositions of reluctance, frustration, and shame' among some deprived individuals - that, 'It is as though these people are perceptually damaged' - without feeling a degree of discomfort. Indeed, even though it is made clear that this perceptual deficit results from 'a taught inability', how one deals with such profound alienation without resorting to some kind of paternalism is difficult to see. The problem here is compounded by McNay's acknowledgement of the problem of assuming a lively democratic ethos that requires 'a certain level of political virtuosity and articulacy that, arguably, in an era of declining political participation, is not especially evident amongst citizens' (p. 92). It is right to point to the atrophy of a certain kind of civil politics (though others would argue that new forms of political participation and protest offer more promise of a different political future), but then the chances of engendering greater social equality would seem slim without the kind of committed activist government of the left that seems a distant prospect in most Western democracies.

Perhaps, then, the more 'constructive' part of McNay's argument is an instance of wishful thinking. A politics of autonomy and active civil participation is a forlorn hope in the absence of substantive conditions of social equality and inclusion that might only be made possible by means of a paternalistic and even mildly authoritarian form of politics. This brings us to the second note of caution, which has to do with McNay's view of the purpose of radical democratic theory, and indeed 
a critical political theory more generally, as 'disclosing critique', with the primary 'practical aim of unmasking domination and, in so doing, revealing possible paths to emancipation' (p. 209). Much depends here on what is construed by 'possible' paths to emancipation. There is always the possibility that a sociologically informed view of the phenomenology of misery might lead us to the miserable conclusion that such misery is so deeply embodied and structured as to mean there are no 'possible' paths to emancipation. 'Miserabilism' cannot be conjured away by theoretical fiat, by the mere assertion of 'the intertwinning of fact and norm' (p. 210). McNay takes to task 'realist' political theorists such as Raymond Geuss for having a 'bleak vision of the real', which is no 'more persuasive and compelling than any other account' (p. 211). But perhaps it is more persuasive because it makes sense to a reflective understanding of the complex conditions of power in the contemporary world that have evidently produced and continue to produce considerable social and political injustice to which there seems no expeditious end. To argue as McNay does for a more (theoretically) modest political theory that is problem-oriented, inter-disciplinary and more phenomenologically reflective about the social conditions that are its concern, is not in itself objectionable. But there is a good case to be made for rebutting attempts to impose on political theory the task of discovering 'paths to emancipation'. It is not clear to me why we should accept this as an obligation of political theory rather than of political practice, two activities that are and should continue to be seen as quite distinct.

Jason Edwards

Birkbeck, University of London, London WC1E 7HX, UK j.edwards@bbk.ac.uk 